\title{
Why English?
}

The major topic which the publisher and the Editors-inChief of the journal VisZERALMEDIZIN have repeatedly addressed in recent years is the question of perception of the excellent articles which we publish in every issue. Our special topics are acknowledged as 'state of the art' - with articles from experts who strive to share their knowledge with you. In order to also receive attention and citations internationally, however, these articles have to be published in English. Another important objective is the acceptance in Medline, which appears more promising with English-language papers.

Thus, the publisher and the Editors-in-Chief decided to actively push the international awareness of the journal: As from now, all articles for the special topics will be written and published exclusively in English. Hence you are now holding the first English-language issue of VISZERALMEDIZIN in your hands!
What else is changing? The guest editors of the individual issues will each select an article which will be made freely available online as 'Editor's Choice' and prominently placed on the website of the journal. In addition, the publisher will make all English-language articles freely available online on the journal's website 1 year after publication. This prerequisite enables us to place the articles at the disposal of the PubMed Central database, consequently making them available via PubMed.

We are pleased with the development of the journal which is now in its 30th year of publication, and we hope that you will continue to read each issue with enthusiasm and benefit from the experience and efforts of the editors and authors.

S. Karger Verlag

\section{KARGER}

Fax +497614520714 Information@Karger.com www.karger.com 